\title{
Assessment of Microbiological Quality of Food Items Served in College Canteens
}

\author{
Anjali Kumari ${ }^{1}$, Surinderjit Kaur ${ }^{2}$ and Sharanbir Kaur Bal ${ }^{3 *}$ \\ Department of Family Resource Management, College of Community Science, Punjab \\ Agricultural University Ludhiana, Punjab, India \\ *Corresponding author
}

\section{A B S T R A C T}

Keywords

Food safety, Consumption, Food quality, Hygiene, Nutritional value, Microbiological quality

Article Info

Accepted:

10 October 2019

Available Online:

10 November 2019
Food holds an important role in human's health, thus a high level of food safety is needed to ensure that human is safe from diseases or dangers that come from foods. Over the past decade, an increased tendency to consume meals at dining facilities outside the home has been highlighted, very often, meals supplied in food businesses are cause of many food borne disease outbreaks. So an effort was made to evaluate the microbiological quality of the selected canteen food items and preparation of guidelines for canteen visitors and workers regarding food quality and hygienic practices. The surprising result of this study was that none of the selected canteen owners had registered themselves under FSSA 2011. Further, the results of microbial examination of selected samples revealed that all the tested sweet as well as salted items were highly contaminated with yeast, mold and bacteria which can be a source of many health problems. Thus, there is a need to educate the students to look into the hygiene, nutritional value of food being served in their canteen and develop taste for healthy foods. It is also essential for the college authorities to keep an eye on what is being served to students in canteens.

\section{Introduction}

Health, vitality, working efficiency, contentment and the enjoyment of life depend on the quality as well as the quantity of food consumed by the individual. Food holds an important role in human's lives, thus a high level of food safety is needed to ensure that human is safe from diseases or dangers that come from foods. Food safety is defined as a condition and needed efforts to avoid foods to be contaminated from biological, chemical contamination agents and other substances that could disturb, harm and endanger human health. In the past two decades there has been a significant change in the dietary habits of people. There has been a shift from traditional home cooked food that is healthier and well 
balanced to outside cooked or processed food. This change can be attributed to busy life style and increased preference to convenient foods available in market. Educational institutions are in a good position to endorse healthy food related behaviours in students and help ensure appropriate food intake. Food items sold in and around the colleges during working hours or break time play a special role in college life because it provides refreshment and energy requirements of students. It has an impact on curricular and co-curricular activities and well -being of students and the college community. But, if the food is prepared, stored and served in hygienic conditions, then it can lead to many health risks. So, food safety is important in food service centres.

In the market food safety is a predictor for well-educated consumers to buy a certain food (Michaelidou and Hassan, 2008). Though contamination could be from biological and chemical substances, most of food-borne diseases $(90 \%)$ are mainly caused by microbial contamination (Purtiantini, 2010). It is an established fact that once food is subjected to the attack of microorganisms the microbial population increases within a few hours' time at normal temperature, because food is an ideal culture medium for multiplication of a variety of microorganisms. Raw foods are the vehicles of food borne diseases, since contaminating pathogens in it are virulent and able to survive the completion of other microbes and multiply during conditions of storage of food. The largest proportion of food-borne diseases in our country is probably caused not by commercially processed foods may survive even cooking for shorter period or may even multiply if proper hygienic precautions are not taken. Therefore, it is necessary to examine the bacteriological quality of food being served in college canteens, for recommending effective sanitary control in order to protect health of the consumer.

\section{Materials and Methods}

During the experimental phase, from all surveyed canteens, 10 canteens where salted as well as sweet snacks were being regularly served were selected. From each selected canteen one salted and one sweet snack was procured for evaluating their quality through the microbial examination by using standard plate count method, observed by Sutton and Scott (2013). So microbial examination of 20 samples (10 salted and 10 sweet snacks) was done to test the quality of food being served in college canteens. The samples were selected on the basis of maximum daily consumption of a particular item in selected canteen. The experiments were conducted in the Science Laboratory of the Department of Microbiology, Punjab Agricultural University, Ludhiana. The detail of the procedure followed for laboratory experiments is as under.

\section{Assessment of Microbial quality of canteen food items}

For the purpose of evaluation of food being served in college canteens, following chemical reagents and tools / equipment were used (Table 1 and 2).

\section{Chemical reagents and equipment used in experiment}

\section{Collection of eatables}

The selected samples of salty and sweet snacks were purchased when freshly prepared and were collected into sterile specimen container. Thereafter, samples were immediately transferred in cooled packs, under aseptic condition in microbiological laboratory (Department of Microbiology, Punjab Agricultural University, Ludhaina) for microbiological analysis within one hour of collection. 


\section{Microbiological examination of eatables}

Enumeration of bacteria from food samples was done for bacterial counts with minimum concentrate types.

\section{Enrichment in Nutrient broth}

Nutrient Broth was used as a pre-enrichment medium for microbiologically testing canteen food samples $5.0 \mathrm{gm}$ of food sample was added to a flask containing $45 \mathrm{ml}$ sterile nutrient broth. The flask was incubated at $37^{\circ} \mathrm{C}$ for 23 hours for growth and maintenance of cultures of bacteria. Samples were diluted as to meet the requirement of calculation which could give the number of colonies at range of 30-300 (Table 3).

\section{Enumeration of bacterial colonies on NA and GYE media respectively}

The pour plate method was used for each diluted food sample for enumerating bacteria and fungi. Subsequent dilutions $\left(10^{-3}\right.$ and $\left.10^{-5}\right)$ were made by adding $0.01 \mathrm{ml}$ of food sample homogenate into a first tube containing 9.99 $\mathrm{ml}$ of sterile water blank and from the first dilution transfer $0.1 \mathrm{ml}$ to second tube containing $9.99 \mathrm{ml}$ of sterile water blank. 1.0 $\mathrm{ml}$ aliquot portions of the dilutions $\left(10^{-3}\right.$ and $10^{-5}$ ) plated on Nutrient Agar and Glucose yeast Extract plates were incubated at $37^{\circ} \mathrm{C}$ for 24 hours and colonies were counted (Table 4 and 5).

\section{Results and Discussion}

Evaluation of different canteens food samples in terms of microbial growth against bacteria

The results of microbial profile of selected food items served in canteens of selected colleges are presented in Table 6.The yeast and mold count for samosa collected from different selected college canteens ranged from $0.7 \times 10^{6} \% \mathrm{gm}$ to $5.3 \times 10^{6} / \mathrm{gm}$. Maximum yeast and mold count was founds in samosa of 'canteen 2' $\left(5.3 \times 10^{6} / \mathrm{gm}\right)$ followed by the samosa from 'canteen 1 ' $\left(4.3 \times 10^{6} / \mathrm{gm}\right)$, 'canteen 3' $\left(5.3 \times 10^{6} / \mathrm{gm}\right)$, canteen 5' $\left(1.9 \times 10^{6} / \mathrm{gm}\right)$ and 'canteen 4 ' $\left(0.7 \times 10^{6} / \mathrm{gm}\right)$. Similarly, kachori was highly contaminated with yeast and mold count $\left(5.7 \times 10^{6} / \mathrm{gm}\right)$ as compared to the other food items selected from different college canteens. This result revealed that food served in college canteens were highly contaminated because foods were held at improper temperatures, workers were wearing unhygienic clothing and following improper food handling practices. So to prevent food borne disease, there is need for regular checking of handling practices and personal hygiene of canteen workers.

Pastry collected from 'canteen 10 ' had high level bacterial count $\left(9.8 \times 10^{4} / \mathrm{gm}\right)$ as compared to sample, collected from other canteens, this may be due to improper handling during transportation which increased the risk of growth of microorganism and led to contamination of food. Bacterial counts $10^{4}$ to $10^{9}$ per gram of food may indicate contaminated raw material, unsuitable time/temperature conditions during production or storage or a combination of these. The International Commission for Microbiological Specification for Foods (1996) states that ready-to-eat foods with plate count between 0 $10^{3}$ is acceptable, between $10^{4} \leq 10^{5}$ is tolerable and $10^{6}$ and above is unacceptable. From the results of present study it is clear that all the tested sweet as well as salted items were highly contaminated which can be the source of many health problems.

Comparison of salted and sweet food items from different college canteen

The results regarding comparison of sweet and salted food samples analyzed from different 
10 college canteens are presented in Table 7. It is evident from results regarding the data that sweet food samples had high bacterial growth i.e. $9.8 \times 10^{4} / \mathrm{gm}$ as compared to salted food samples i.e. $8.4 \times 10^{4} / \mathrm{gm}$. Similarly, yeast and mold count was more on sweet food samples i.e. $6.7 \times 10^{6} / \mathrm{gm}$ as compared to salted food samples i.e. $5.7 \times 10^{6} / \mathrm{gm}$.

Therefore, sweet food samples were more contaminated as compared to salted food samples because salt has an inhibitory property. The presence of bacteria in food showed that the food was contaminated.

Bean et al., (1990) also revealed that contamination of food by a pathogen occurs in canteens, restaurants, fast-food services and cafeterias due to failure to observe proper sanitation, improper cooling of foods, crosscontamination and long interval between preparation and consumption and a large number of people over a wide area will be affected.

\section{Enumeration of total bacterial of food samples of different localities.}

The range of mean microbial count of food samples of different localities are shown in Table 8 . The range of variation of bacterial count in food from different localities was varied. The data in Table 8 revealed that maximum yeast and mold count was observed in salted food samples collected from 'locality 4 ' and it ranged between $1.0 \times 10^{6}$ $5.7 \times 10^{6} \mathrm{cfu} / \mathrm{gm}$, whereas salted food samples collected from 'locality 1' had maximum bacterial count, ranged from $3.1 \times 10^{4}-$ $8.4 \times 10^{4} \mathrm{cfu} / \mathrm{gm}$.

Similarly sweet food samples collected from 'locality 1' had maximum yeast and mold organisms which ranged between $1.8 \times 10^{6}-$ $5.7 \times 10^{6} \mathrm{cfu} / \mathrm{gm}$, while examined sweet item collected from 'locality 4' had maximum bacterial growth and it ranged between $8.8 \times 10^{4}--9.8 \times 10^{4} \mathrm{cfu} / \mathrm{gm}$. So the food served in college canteens were highly contaminated, due to improper handling, processing and storing of food.

The present results are tune with the study conducted by Angelidis et al., (2006) who concluded that the initial microbiological load on canteen food ingredients is important, however, factors such as handling, processing, storage and display may influence the microbiological load of ready to eat foods at the point of sale.

Therefore canteen food had been implicated in food borne illness outbreaks as these foods are often prepared by hands and this direct contact may lead to an increased incidence of contamination with potential food borne pathogens, which can be the source of many health problems.

\section{Guidelines for canteen visitors}

The findings of the study were significant and it was felt that guidelines for safe food selection should be communicated to consumers who do not have access to this research document. These were distributed among canteen visitors to fulfill the purpose of study in its real terms.

\section{Food served on your table must be hot}

Hot food should require being hot which prevent growth of microorganisms should be at $140^{\circ} \mathrm{F}$ when served. Most food requires cooking to higher temperature before they served on the table. Avoid food uncovered.

\section{Cold foods should be served cold}

Foods that are required to be cold to prevent growth of microorganisms should be at temperature $41^{0} \mathrm{~F}$ or less. 
Table.1 Chemical reagents used for experiment

\begin{tabular}{|c|c|c|}
\hline Sr. No. & Chemical Reagents & Purpose \\
\hline 1. & Nutrient broth & Used for growth and maintenance of culture of bacteria \\
\hline 2. & Nutrient Agar & Media used for Standard Plate Count method \\
\hline 3. & Glucose yeast extract & \\
\hline
\end{tabular}

Table.2 Tools / Equipment used for experiment

\begin{tabular}{|c|c|c|}
\hline Sr. No. & Chemical Reagents & Purpose \\
\hline 1. & Electronic balance & For weighting the chemicals (Plate 1 ) \\
\hline 2. & $\begin{array}{l}\text { Measuring instruments } \\
\text { and glass wares }\end{array}$ & Media used for Standard Plate Count method \\
\hline 3. & Laminar & $\begin{array}{l}\text { For preventing the bacterial growth at the time of } \\
\text { microbial evaluation (Plate } 2 \text { ) }\end{array}$ \\
\hline 4 & Autoclave & For inhibition of microbial growth (Plate 3) \\
\hline 5 & Incubator & $\begin{array}{c}\text { For specific growth of microorganism on particular } \\
\text { temperature. }\end{array}$ \\
\hline 6 & Oven & For sterilization accomplish by dry heat. \\
\hline
\end{tabular}

Table.3 Composition of Nutrient Broth (NB)

\begin{tabular}{|c|c|c|}
\hline Sr. No. & Ingredients & Quantity \\
\hline $\mathbf{1 .}$ & Peptone & $5 \mathrm{~g}$ \\
\hline $\mathbf{2 .}$ & Sodium chloride & $5 \mathrm{~g}$ \\
\hline $\mathbf{3 .}$ & Beaf extract & $3 \mathrm{~g}$ \\
\hline $\mathbf{4 .}$ & Distilled water & $1000 \mathrm{ml}$. \\
\hline
\end{tabular}

$\mathrm{pH}: 6.8 \pm 0.2$ at $25^{\circ} \mathrm{C}$

Table.4 Composition of Nutrient Agar Medium (NA)

\begin{tabular}{|c|c|c|}
\hline Sr. No. & Ingredients & Quantity \\
\hline $\mathbf{1 .}$ & Peptone & $5 \mathrm{~g}$ \\
\hline $\mathbf{2 .}$ & Sodium chloride & $5 \mathrm{~g}$ \\
\hline 3. & Beaf extract & $3 \mathrm{~g}$ \\
\hline $\mathbf{4 .}$ & Distilled water & $1000 \mathrm{ml}$. \\
\hline $\mathbf{5 .}$ & Agar & $20 \mathrm{~g}$ \\
\hline
\end{tabular}


Table.5 Composition of Glucose Yeast Extract (GYE)

\begin{tabular}{|c|c|c|}
\hline Sr. No. & Ingredients & Quantity \\
\hline $\mathbf{1 .}$ & Glucose & $10 \mathrm{~g}$ \\
\hline $\mathbf{2 .}$ & Peptone & $5 \mathrm{~g}$ \\
\hline $\mathbf{3 .}$ & Yeast extract & $5 \mathrm{~g}$ \\
\hline $\mathbf{4 .}$ & Distilled water & $1000 \mathrm{ml}$ \\
\hline $\mathbf{5 .}$ & Agar & $20 \mathrm{~g}$ \\
\hline
\end{tabular}

pH.6.8.-7.2

Table.6 Mean microbial profile of various sample of food served in different college canteens (cfu/gm)

\begin{tabular}{|c|c|c|c|}
\hline Sr. No. & Food Sample & $\begin{array}{l}\text { Yeast and mold on } \\
\text { GYE media }\end{array}$ & $\begin{array}{c}\text { Bacterial count on } \\
\text { NA media }\end{array}$ \\
\hline \multirow[t]{2}{*}{1.} & Samosa & $4.3 \times 10^{6}$ & $8.4 \times 10^{4}$ \\
\hline & Barfi & $5.2 \times 10^{6}$ & $7.5 \times 10^{4}$ \\
\hline \multirow[t]{2}{*}{2.} & Samosa & $5.3 \times 10^{6}$ & $5.6 \times 10^{4}$ \\
\hline & Gulabjamun & $6.7 \times 10^{6}$ & $9.4 \times 10^{4}$ \\
\hline \multirow[t]{2}{*}{3.} & Samosa & $2.2 \times 10^{6}$ & $3.1 \times 10^{4}$ \\
\hline & Pastry & $1.8 \times 10^{6}$ & $2.5 \times 10^{4}$ \\
\hline \multirow[t]{2}{*}{4.} & Samosa & $0.7 \times 10^{6}$ & $3.8 \times 10^{4}$ \\
\hline & Pastry & $5.1 \times 10^{6}$ & $4.6 \times 10^{4}$ \\
\hline \multirow[t]{2}{*}{5.} & Samosa & $1.9 \times 10^{6}$ & $3.8 \times 10^{4}$ \\
\hline & Barfi & $0.8 \times 10^{6}$ & $7.3 \times 10^{4}$ \\
\hline \multirow[t]{2}{*}{6.} & Noodles & $2.1 \times 10^{6}$ & $6.7 \times 10^{4}$ \\
\hline & Pastry & $4.8 \times 10^{6}$ & $7.1 \times 10^{4}$ \\
\hline \multirow[t]{2}{*}{7.} & PaneerPakora & $1.2 \times 10^{6}$ & $4.3 \times 10^{4}$ \\
\hline & Pastry & $3.0 \times 10^{6}$ & $2.7 \times 10^{4}$ \\
\hline \multirow[t]{2}{*}{8.} & PaneerPakora & $1.8 \times 10^{6}$ & $1.0 \times 10^{4}$ \\
\hline & Gulabjamun & $4.2 \times 10^{6}$ & $4.2 \times 10^{4}$ \\
\hline \multirow[t]{2}{*}{9.} & Kachori & $5.7 \times 10^{6}$ & $6.1 \times 10^{4}$ \\
\hline & Pastry & $1.5 \times 10^{6}$ & $8.8 \times 10^{4}$ \\
\hline \multirow[t]{2}{*}{10.} & Samosa & $1.0 \times 10^{6}$ & $6.5 \times 10^{4}$ \\
\hline & Pastry & $1.7 \times 10^{6}$ & $9.8 \times 10^{4}$ \\
\hline
\end{tabular}

Incubation period : Bacteria growth -48 hours ; Yeast and mold growth -6 days Incubation temp $-37^{0} \mathrm{C}$ 
Table.7 Comparison of salted and sweet food items from different college canteen (cfu/gm)

\begin{tabular}{|c|c|c|c|c|c|c|}
\hline Canteen & $\begin{array}{c}\text { Salted food } \\
\text { samples }\end{array}$ & $\begin{array}{c}\text { Yeast and } \\
\text { mold } \\
\text { growth on } \\
\text { GYE } \\
\text { media }\end{array}$ & $\begin{array}{c}\text { Bacterial } \\
\text { growth on } \\
\text { NA media }\end{array}$ & $\begin{array}{c}\text { Sweet Food } \\
\text { samples }\end{array}$ & $\begin{array}{c}\text { Yeast and } \\
\text { mold } \\
\text { growth on } \\
\text { GYE } \\
\text { media }\end{array}$ & $\begin{array}{c}\text { Bacterial } \\
\text { growth on } \\
\text { NA media }\end{array}$ \\
\hline 1. & Samosa & $4.3 \times 10^{6}$ & $8.4 \times 10^{4}$ & Barfi & $5.2 \times 10^{6}$ & $7.5 \times 10^{4}$ \\
\hline $\mathbf{2 .}$ & Samosa & $5.3 \times 10^{6}$ & $5.6 \times 10^{4}$ & Gulabjamun & $6.7 \times 10^{6}$ & $9.4 \times 10^{4}$ \\
\hline $\mathbf{3 .}$ & Samosa & $2.2 \times 10^{6}$ & $3.1 \times 10^{4}$ & Pastry & $1.8 \times 10^{6}$ & $2.5 \times 10^{4}$ \\
\hline $\mathbf{4 .}$ & Samosa & $0.7 \times 10^{6}$ & $3.8 \times 10^{4}$ & Pastry & $5.1 \times 10^{6}$ & $4.6 \times 10^{4}$ \\
\hline $\mathbf{5 .}$ & Samosa & $1.9 \times 10^{6}$ & $3.8 \times 10^{4}$ & Barfi & $0.8 \times 10^{6}$ & $7.3 \times 10^{4}$ \\
\hline 6. & Noodles & $2.1 \times 10^{6}$ & $2.1 \times 10^{4}$ & Pastry & $4.8 \times 10^{6}$ & $7.1 \times 10^{4}$ \\
\hline 7. & PaneerPakora & $1.2 \times 10^{6}$ & $4.3 \times 10^{4}$ & Pastry & $3.0 \times 10^{6}$ & $2.7 \times 10^{4}$ \\
\hline 8. & PaneerPakora & $1.8 \times 10^{6}$ & $1.8 \times 10^{4}$ & Gulabjamun & $4.2 \times 10^{6}$ & $4.2 \times 10^{4}$ \\
\hline 9. & Kachori & $5.7 \times 10^{6}$ & $6.1 \times 10^{4}$ & Pastry & $1.5 \times 10^{6}$ & $8.8 \times 10^{4}$ \\
\hline $\mathbf{1 0 .}$ & Samosa & $1.0 \times 10^{6}$ & $1.0 \times 10^{4}$ & Pastry & $1.7 \times 10^{6}$ & $9.8 \times 10^{4}$ \\
\hline
\end{tabular}

Table.8 Enumeration of total bacterial count of food samples of different localities

\begin{tabular}{|c|c|c|c|c|c|}
\hline \multirow{2}{*}{ Locality } & Range & \multicolumn{2}{|c|}{ Salted food item } & \multicolumn{2}{|c|}{ Sweet food item } \\
\cline { 2 - 5 } & & $\begin{array}{c}\text { Yeast and mold } \\
\text { growth }\end{array}$ & $\begin{array}{c}\text { Bacterial } \\
\text { growth }\end{array}$ & $\begin{array}{c}\text { Yeast and mold } \\
\text { growth }\end{array}$ & $\begin{array}{c}\text { Bacterial } \\
\text { growth }\end{array}$ \\
\hline \multirow{2}{*}{ 1. } & Min. & $0.7 \times 10^{6}$ & $3.1 \times 10^{4}$ & $1.8 \times 10^{6}$ & $2.5 \times 10^{4}$ \\
\cline { 2 - 6 } & Max. & $5.3 \times 10^{6}$ & $8.4 \times 10^{4}$ & $5.4 \times 10^{6}$ & $9.4 \times 10^{4}$ \\
\hline \multirow{2}{*}{ 2. } & Min. & $1.9 \times 10^{6}$ & $3.8 \times 10^{4}$ & $1.8 \times 10^{6}$ & $7.1 \times 10^{4}$ \\
\cline { 2 - 6 } & Max. & $2.1 \times 10^{6}$ & $5.7 \times 10^{4}$ & $4.8 \times 10^{6}$ & $7.3 \times 10^{4}$ \\
\hline \multirow{2}{*}{ 3. } & Min. & $1.2 \times 10^{6}$ & $1.2 \times 10^{4}$ & $3.0 \times 10^{6}$ & $2.7 \times 10^{4}$ \\
\cline { 2 - 6 } & Max. & $1.8 \times 10^{6}$ & $4.3 \times 10^{4}$ & $4.2 \times 10^{6}$ & $4.2 \times 10^{4}$ \\
\hline \multirow{2}{*}{ 4. } & Min. & $1.0 \times 10^{6}$ & $2.1 \times 10^{4}$ & $1.5 \times 10^{6}$ & $8.8 \times 10^{4}$ \\
\cline { 2 - 6 } & Max. & $5.7 \times 10^{6}$ & $6.5 \times 10^{4}$ & $1.7 \times 10^{6}$ & $9.8 \times 10^{4}$ \\
\hline
\end{tabular}

Cold foods left at room temperatures often grow bacteria within 2 hours. If foods aren't at the right temperature, don't eat them.

\section{Check hygiene condition of the server}

While eating in canteen look at the server i.e. hands and fingernails should be clean; they keep their hands away from their face and hair and they should wear clean protective clothing. Burn, cuts or wounds should be properly covered with clean bandage as foodborne illness can be passed from person to person. Burns and cuts that may be infected are also a good source of harmful bacteria.

Plates, glasses and utensils should be clean and spot free

If they have dried-on food, finger prints or lipsticks on glasses and then the dishwasher is likely on the blink, ask for clean replacement or move. 
Fresh foods such as fruits and vegetables should look and smell fresh

Wilted salads may be an indication that the product is old or has not been properly handled.

\section{Check for any bugs}

See cockroaches or flies near your table, it's time to leave.

\section{Check for general condition of college canteen environment}

The canteen should be well lit, airy and clean.

\section{Raise your voice}

If you have problem, speak up. First explain the problem to your canteen workers, be as courteous, claim and matter-of-fact as possible. If that doesn't work, talk to the owner and then to management.

The maximum percentage of students (53.1 percent) preferred to visit college canteen daily for eating and majority of respondents visited college canteen in lunch time and spent Rs. 50- Rs 100 per day on canteen food.

The majority of respondents were highly dissatisfied with the quality of food, sanitary conditions, ambience and sitting arrangement of their canteens.
Further the results of experimental study of selected samples revealed that all the tests of sweet as well as salted items were highly contaminated with yeast, mold and bacteria which can be source of many health problems.

\section{References}

Anonymous (1988) Bacteriological quality. pp 8-15, Retrieved on October, 2014 http://dsp-psd.pwgsc.gc.ca/Collection/ H48-10-1-3-1991E.pdf

Bean N, Griffin P M, Giulding J S and ivey CB (1990) food borne disease outbreak 5- year summary. J food Professional 53:711

Ghosh M, Wahi S, Kumar M and Ganguli $\mathrm{H}$ (2007) Prevalence of enterotoxigenic Staphylococcus aureus and Shigella species in some raw street vended Indian foods. J Environ Health Res 17:151-56

Michaelodou $n$ and Hassan L M (2008) The role of health consciousness, food safety concern and ethical identity on attitude and intensions towards organic food. Inter J Consumer Studies 32: $163-70$

Peraica M and domijan A M (2001) Mycotoxins in food and human health. $\mathrm{J}$ Achieves Industrial Hygiene Toxicology 30: 23-35

Sutton and Scott (2013) Microbiology Topics. Accuracy of plate counts. http: //www. Microbiol.org/wp-conyent/uploads/ 2010/07/Sutton.jvt_2011.17_3.pdf

\section{How to cite this article:}

Anjali Kumari, Surinderjit Kaur and Sharanbir Kaur Bal. 2019. Assessment of Microbiological Quality of Food Items Served in College Canteens. Int.J.Curr.Microbiol.App.Sci. 8(11): 974981. doi: https://doi.org/10.20546/ijcmas.2019.811.114 